\title{
Kentin Kültürel Aktarım Mekânları Muğla Kent Merkezi Örneği
}

\author{
Aslı ÇANDARLI ŞAHİN*
}

\begin{abstract}
ÖZ
Gündelik yaşam deneyimleri her koşulda bir mekânda geçmekte; olaylara fon oluşturan mekânlar, insanlar için kimi zaman gerçekte olduğundan çok daha fazlasını ifade etmektedir. Bu noktada toplum bireylerinin kent mekânlarını algılama biçimleri farklılık gösterebilir. Nitekim her bir birey mekâna kendi yaşanmışlıkları üzerinden bakmakta ve bu doğrultuda bir anlam yüklemektedir. Ne var ki, kent mekânları, bireysel deneyimlerin yanı sıra toplumsal ilişkilerin birebir yaşandığ1 yerler olarak da öne çıkmakta ve bu yönüyle gerek toplum hafızasının gerekse kent kimliğinin oluşmasına önemli bir katkı sunmaktadır. Bu çalışma, kültürlerin üretildiği ve aktarıldığg kent mekânlarının insanların aidiyet duygularının gelişmesinde ve sosyalleşmelerinde önemli bir etkiye sahip olduğu varsayımı üzerine kuruludur. Zira kent sakinleri çeşitli mekânlarda bir araya gelmektedir ve bunu sağlayan, o mekânların işlevsel özelliklerinden çok insanlara sundukları bütünleştirici fakat bir o kadar da ayrıştırıcı sosyalliktir. Nitekim kentte bulunan her bir mekân yaşamı kolaylaştırıcı bir takım özelliklerinin yanı sıra aslında bünyesinde barındırdığı yerellik ve semboller sayesinde gerek kentlere gerekse sakinlerine bir kimlik üretmektedir. Çalışmada mekân ve insan arasındaki etkileşim Muğla kent merkezi örneği üzerinden vurgulanmıştır. Metot olarak belgelerin eksik bıraktıklarını tamamlama ya da bildirdiklerinin sağlamasını yapabilme noktasında önemli veriler sunan sözlü tarih kullanılmıştır. $\mathrm{Bu}$ doğrultuda gerçekleştirilen sözlü görüşmeler kentteki buluşma mekânlarının kent sakinleri tarafından nasıl algılandığı, onların hafızalarına nasıl kazındığı, toplumsal ilişkilerin gelişmesine herhangi
\end{abstract}

Dr., Muğla Sıtkı Koçman Üniversitesi, Edebiyat Fakültesi, Tarih Bölümü, Muğla/Türkiye E-posta: aslicandarli@mu.edu.tr, ORCID: 0000-0002-0076-0064, DOI: 10.32704/erdem.948836 Makale Gönderim Tarihi: 17.05.2019* Makale Kabul Tarihi: 26.03.2021 * (Araştırma Mk.) 
bir katkı sunup sunmadığı gibi konularda oldukça aydınlatıcı olmuştur. Kent sakinlerinin geçmişe duydukları özlemle birlikte anlattıklarına kulak verince ilk dikkat çeken, bir zamanlar Muğla'sında insanların günümüze nispeten daha samimi ve içten bir komşuluk ilişkisi yaşadığıdır. Mahalle başta olmak üzere pazar, kahvehane, sinema ve park gibi mekânlar kültürel aktarım mekânları olarak kent tarihindeki yerini almış durumdadır. Ne var ki, zaman içinde gerek mekânlarda gerekse insan ilişkilerinde bir değişim ve dönüşüm yaşanmıştır. Çalı̧̧mada kentin kültür tarihi mekân-insan ilişkisi üzerinden aydınlatılmaya çalışılmıştır.

Anahtar Kelimeler: Kültür, yerel tarih, sözlü tarih, kent, Muğla 


\title{
Culture Transfer Locations of the City Mugla City Center Example
}

\begin{abstract}
Everyday experiences occur in a place in every situation; the places that provide a base for the events are much more important for people than they are. The way individuals perceive urban places may differ. In fact, everyone looks at the place through their experiences and provides a meaning in this direction. However, urban places stand out as the places where social relations are experienced, as well as individual experiences, and with this aspect, it makes an important contribution to the forming of the social memory and the city identity. This study assumes that urban places where cultures are produced and transferred have a significant impact on the socialization and development of people's sense of belonging. Because the inhabitants of the city come together in various places and what provides this is the parser socialism rather than the functional features of those places. In fact, every place in the city creates an identity for cities and its inhabitants thanks to its locality and symbols, which are in fact a structure that facilitates life. In this study, the interaction between place and human is emphasized with the example, the central district of Mugla. Oral history was used as a method to provide important data for completing missing documents or crosscheck the reports. Verbal interviews was enlightening about how the meeting places in the city were perceived by the city residents, how they were engraved in their memory and whether they made any contribution to the development of social relations. In this study, the culture and history of the city have been tried to be elucidated through the place-human relationship.
\end{abstract}

Keywords: Culture, local history, oral history, city, Mugla 


\section{Giriş}

$\mathbf{H}$ er bireyin, her mekânın kendi tarihinin olduğu düşüncesi bu tarihin aydınlatılması çabasını beraberinde getirmiş ve böylelikle yerel tarih araştırmaları giderek gelişme sağlamıştır (Caunce 2017: 8). Ulusal ya da uluslararası siyasi ve askeri gelişmeler, bürokratik yazışmalar, idareciler ve uygulamaları nasıl ki, insanlık açısından önemli ve araştırılmaya değer ise; yaşanılan çevre ve bünyesinde barındırdı̆̆ 1 tarihi, coğrafi, kültürel özellikler de aynı şekilde bütünün bir parçasıdır. Tarih biliminin, belge ve siyasi olaylar odaklı bakış açısı özellikle 20. yüzyıl ile birlikte daha toplum odaklı bir hal almıştır (Danacıoğlu 2001: 2-3; Tosh 2011: 91). Bu noktada yerel tarih araştırmaları sıradan insanların ve onların yaşadıkları yerlerin de anlatılmaya değer olduğunu göstermesi açısından önemlidir. Yaşanılan bölgenin, kentin ya da mahallenin özgünlüğünü vurgulamak, zaman içinde geçirdiği toplumsal, kültürel ve iktisadi dönüşümü ortaya koymak yerel tarihin temel yaklaşımıdır (İlyasoğlu 2001: 39, Iş1k 2008: 291-292).

Bilindiği üzere sözlü tarih herhangi bir döneme ya da olaya ilişkin kişisel tanıklıklardan faydalanarak toplumsal tarihin aydınlatılmasına katkı sunan bir araştırma yöntemi olarak öne çıkmakta, yerel tarih araştırmaları için kullanılacak metotların başında gelmektedir. (Danacıŏlu 2001: 133, 22). Aslına bakılırsa tarih ve söz arasındaki ilişkinin varlığı, yüzyıllar öncesine dayanır. O kadar ki, tarih yazımının doğuşunun; anlatının yazıya geçirilmesi suretiyle gerçekleştiği söylenebilir (Thompson 1999: 24; Danacıoğlu 2001: 131, 135; Tosh 2011: 203). Bir kültürü gerçek anlamda öğrenmenin en iyi yolu, onu yaşayan ve yaşatan halktan öğrenmektir (Önal 2007:24). Kendilerini herhangi bir olayın öznesi olarak görmeyen insanların yaşam rutini içinde sıradan gördükleri olaylar ${ }^{1}$ sözlü tarih metodu sayesinde öne çıkmaktadır (Caunce 2017:8). Herhangi bir konunun aydınlatılması adına yaşadıklarını aktaran, deneyimini paylaşan kişi bu sayede bir farkındalık yaşamakta, zamana ve mekâna karşı bir aidiyet geliştirmektedir (Thompson 1999: 18). Yerel tarih ve sözlü tarih söz konusu olduğunda çoğu zaman uzak geçmiş değil "bugünün dünü” yani hemen yanı başımızdaki tarihe yönelim vardır (Danacıŏlu 2001: 133, 22). Bu araştırmada da yazılı kaynakların yanı sıra günümüzde yaşayan ve yaşları gereği kentin yakın geçmişine bizzat şahitlik eden kişilerin bilgileri doğrultusunda Cumhuriyet'in ilk yıllarından 1970'lere kadar geçen süre içinde kentin kültürel durumu incelenmiştir.

Yerel tarih araştırmaları gözlem ve yaşama pratiği ile doğrudan ilgilidir. Bu noktada bilgiye ulaşma konusunda sahip olacağımız avantajlar düşünüldü- 
günde neden araştırma mekânı olarak yaşadığımız kente, en yakınımızdakine odaklandığımız kendiliğinden ortaya çıkacaktır. Bu çalışmaya konu olan Muğla kent merkezi, geleneksel kent dokusu izlerinin günümüzde de yaşatıldığı bir yerleşim yeri olma özelliği taşımaktadır. Nitekim Arasta’sı, Yağcılar Hanı, bir dönem yurtluk yaptığı Rum sakinlerinin izlerini taşıyan Saburhane Semti ${ }^{2}$, Filvari Usta'nın elinden çıkan ve hâlâ saat başı çalarak zamanı bildiren Saatli Kule'si (Tekeli 2006:167) ile geleneksel olanı muhafaza etme gayretinde bir kent görüntüsü çizmektedir. Bununla birlikte zamanın değişmekte olan şartlarına ayak uydurup yaşanması gereken gelişim sürecinin sürmekte olduğu da göz ardı edilemez. Zira zaman; kenti, insanları ve ilişkileri değiştirip dönüştürmektedir.

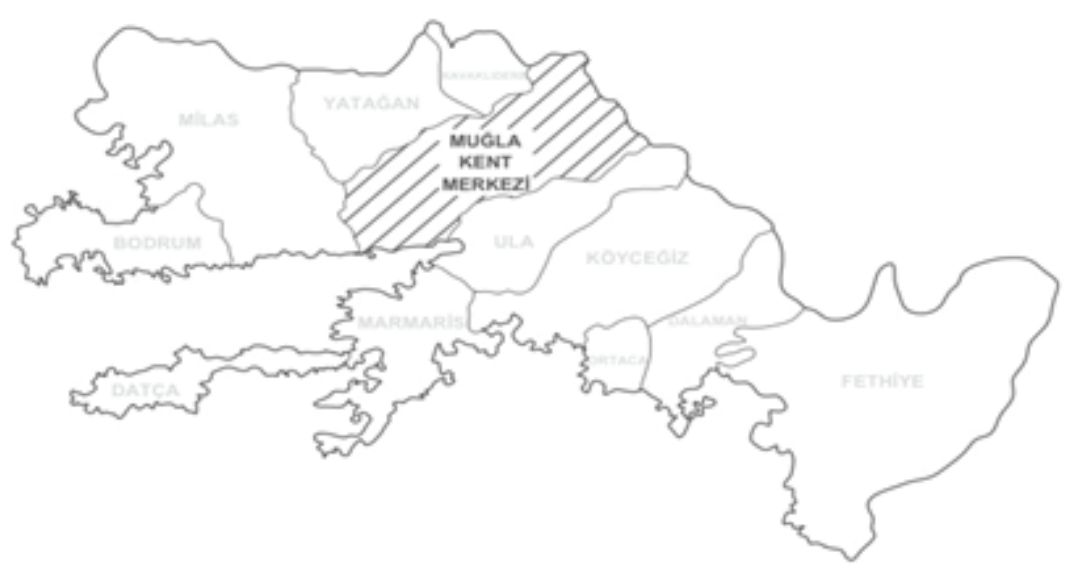

Harita: Muğla kent merkezi ${ }^{3}$

Araştırmada tarih içinde kentte meydana gelen mekânsal değişim ve bununla bağlantılı olarak insan ilişkilerindeki dönüşüm ele alınmaktadır. Dolayısıyla kent tarihi, kentin kültür tarihi mekânlar üzerinden aydınlatılmaya çalış1maktadır.

Düşünülürse her birey genç yaşlarında anne babasının "bizim zamanımızda...” diye başlayan cümlelerini hayıflanarak dinlemekte; ancak günün birinde kendisi de eski şarkıları, eski filmleri, çocukluğunun bayramlarını, "bir zamanlar"1 arayan birer insan haline dönüşmektedir. İşte bu çalışma; iletişim imkânlarının, teknolojik koşulların günümüzdeki kadar gelişmediği “bir zamanlar Muğla’sında" insanların birbiriyle nasıl iletişim kurduğu sorusunun cevabının arayışı içindedir. Muğla’nın gündelik yaşamı için ortaya, eskiden kalma siyah-beyaz bir 
fotoğraf koyma niyet ve gayretini taşımaktadır. Teknolojinin henüz gündelik yaşama girmediği zamanlarda, televizyonun değil radyonun izlendiği (dinlerken bakılırmış da) telefonun ceplerde, evlerde değil sadece postanelerde ya da belli başlı dükkânlarda bulunduğu, insanların mesajlaşmadığı mektuplaştığı dönemlerde vakit nasıl geçerdi, insanlar kendi dışındakiler ile nerede bir araya gelir ve dış dünyadan nasıl haber alırdı, mekânlar yerel kültür için ne anlam ifade ederdi gibi sorulara cevap aranmıştır.

\section{Sosyal İlişkiler, Hafıza, Aidiyet ve Mekân}

Toplumu meydana getiren şey bireyler arasındaki etkileşimse eğer, toplum hakkında bilgi sahibi olmanın, sosyal işleyişi anlamanın en kestirme yolu gündelik hayatın ayrıntılarına odaklanmaktır (Lefebvre 1968/1998: 35'ten aktaran Binay ve Tatlıcan 2018: 180). Her kent sakinleriyle, gelenek ve görenekleriyle, coğrafi özellikleriyle ve mekânlarıyla bir takım kendine özgülüklere sahiptir. Kent orada yaşayan insanların ticari, dini, kültürel bazı ihtiyaçlarına cevap verme amacına hizmet eden çeşitli mekânlar sayesinde yaşanılır bir yer olmaktadır. Bu durumda kentin ana karakterini ortaya koyan unsurların başında mekânın geldiğini düşünmek yanlış olmayacaktır. Zira mekân kentin biçimsel oluşumunun en önemli öğesidir. Aslına bakılırsa tüm kent dokusu mekândan türemekte ve mekân çevresinde oluşan ilişkiler ağ i ile birlikte bir bütün oluşturmaktadır (Demirseren Çöl 1998:11). Dolayısıyla bir kenti anlamanın öncelikli yolu, mekâna ve orada yaşananlara bakmaktan geçmektedir. Toplumsal olayların gerçekleştiği, gündelik yaşamın aktığı çeşitli mekânlar olayların içeriğini de biçimlendirir (Sztompka 2008: 10'dan aktaran Binay ve Tatlıcan 2018: 184). Mekân üretim biçimleri ve ilişkileri içerisinde üretilir (Lefebvre 2010: 253). Bu noktada aslında tarihin her döneminde başlangıçta insan tarafindan oluşturulan mekân zaman içinde insanların hayatlarını şekillendiren bir etkiye sahip olmuştur. Düşünülürse; insanın gündelik yaşam içinde edindiği tecrübeler, bu tecrübelere tanıklık eden mekânları da anlamlı hale getirip insan ve mekân arasında farklı bir bağın oluşmasını sağlamaktadır. Yerel kültür kentin çeşitli mekânlarında oluşmakta ve dahası bu mekânların da katkısı ile paylaşılmakta ve kendine özgü bir hâl almaktadır (Aytaç 2007:201-202).

Kent sakinleri için tesadüfi karşılaşmalar ya da bilinçli buluşmalar yaratan mekânlar bir arada olma, konuşarak haber alma, paylaşma, kültür üretme, dayanışma ve etkileşim içinde olmaya imkân sağlayan yerlerdir. Toplumsal mekân, gündelik yaşamın olmazsa olmazıdır (Lefebvre 2010: 245). Ancak 
gündelik yaşama fon oluşturmanın yanında aidiyet duygusunu teşvik eden bir özelliğe sahiptir (Ergin 2001:233-234). Bireylerin içinde bulunduklar1 dünyayı tanımaları ve anlamlandırabilmeleri, bulundukları ortama adapte olabilmelerinin önünü açar (Binay ve Tatlıcan 2018: 174-175). Mekânlar kent sakinlerinin o kentte kendilerine bir yer bulabilmelerini, özel olan ev dışında da bir aidiyet alanı oluşturabilmelerini sağlamaktadır. Başka bir ifade ile zaman içinde mekânlar asıl işlevlerinden çok daha fazlasını ifade etmeye başlamaktadır. Nitekim düzenli olarak aynı mekânı paylaşanlar arasında ister istemez bir kaynaşma ve etkileşim yaşanmaktadır. Ortak noktalar keşfedilmiştir. Mekânın sunduğu özgünlükte insan kendine ait bir şeyler bulur, aradığ1 yüzleri görür, huzurlu ve özgür hisseder. Mekân, kent sakinleri için tanınmak, bağlanmak, aidiyet, sahiplik gibi çeşitli duyguları tattıkları bir yer haline gelir (Aytaç 2007:200-201,203,221). Bu noktada mekânlar ve yaşanmışlıklar doğrultusunda bu mekânlara yüklenen anlamlar iletişimin ve etkileşimin en öncelikli unsurlarındandır. Zira söz konusu yerler kent içinde birbirine yabancı bir toplum yerine fikir alış verişlerinin yaşandığı, tecrübelerin paylaşıldığı ve birbirini etkilediği bir ortam sunar. Etkileşim ve paylaşımın çoğalması ile doğru orantılı olarak mekânın hafızadaki yeri ve anlamı derinleşir. Bağllılık ve aidiyete dönüşür (Güleç Solak 2017:13,21). Mekânların sunduğu sesler, renkler, kokular da kent sakinlerinin aidiyet duygularını pekiştiren unsurlar olarak öne çıkmaktadır. Örneğin herhangi bir Muğlalı, Kerimoğlu Zeybeğini her duyduğunda ya da bol sarımsaklı-yoğurtlu tarhananın mis gibi kokusunu her içine çektiğinde nerede olursa olsun memleketini düşünecek; göç göç çiçeğinin sarısında yayla anılarını, kuru biberlerin kırmızısında Perşembe Pazarını anımsayacaktır.

Mekânların kent sakinlerinin hafızalarındaki karşılıklarının anlaşılması, kentin kültürel tarihinin ortaya konabilmesi açısından önemlidir. Araştırma süresince gerçekleştirilen sözlü tarih görüşmelerinde edinilen bilgilere göre Muğla kent sakinlerinin hafızasına kazınan önemli aktarım mekânları; mahalle, pazar, kahvehane, sinema ve park olarak öne çıkmaktadır. 


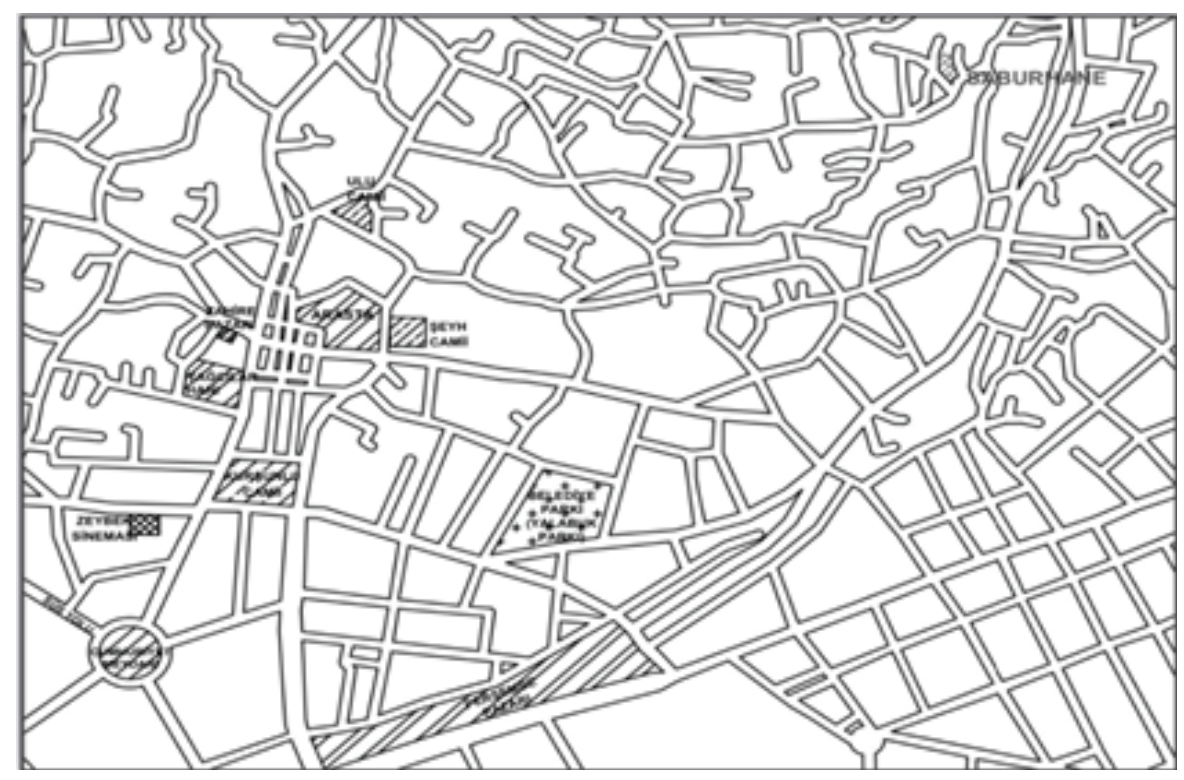

Harita: Makalede adı geçen mekânlar

\section{Mahalle, Sokak}

Mahalle sınırları belli bir alan olmanın yanında birleştirici bir özelliğe de sahiptir. Geleneksel kültürde bir arada olma sanatının sahnelendiği bir alandır. Birey için herhangi bir mahalleyi anlamlandıran şey ilk bakışta yaşamını sürdürdüğü evdir. Ancak devamında buna birçok farklı öğe eklenir (Certeau vd. 2009: 31-33). Aslında kent sakinlerinin en çok kimler ile bir arada bulunup etkileşim içinde olacağını kişinin kendi tercihleri ile birlikte mahalleler belirlemektedir (Greenbaum 1982 ve 1985'den aktaran Talen ve Şahin 2002:152). Zira önce en yakındaki ile iletişim kurulur. Mahalleli olma aynı zamanda "biz" olma anlamına gelmiştir. Kentin kişi için sunduğu genel alana karşın mahalle daha özel bir alan oluşturur ve konut özelinden kent geneline geçişte bir ara uyum süreci yaratır (Certeau vd. 2009: 34-35).

17. yüzyılda Muğla'yı ziyaret eden Evliya Çelebi, kentin 11 mahalleden oluştuğunu belirtmiştir (2011: 105). 19. yüzyıl ortalarında kent için Ahmed Hoca, Bâli Hoca, Bâyezid, Câmi-i Kebir, Deksed, Emir Küçük, Hacı Muslihiddin, Hacı Rüstem, Kara Memi, Kiramüddin, Orta, Şeyh Bedreddin, Yaka ve Gayr-i Müslim biçiminde 14 mahallenin adı geçmektedir (Akgünlü 2008:7-8). 
Genel olarak bakıldığında belediye ve adliye binaları ile Kocamustafaefendi İlkokulu'nun bulunduğu Müştakbey Mahallesi, 1950'lere kadar Muğla kentinin idari merkezi durumunda iken bu tarihten itibaren merkez Cumhuriyet Meydanı çevresine kaymıştır. Müştakbey Mahallesi, Şeyh Mahallesi ile birlikte kentin yüksek gelirli ve sosyal açıdan üst düzey olarak nitelenebilecek sakinlerinin yaşadığı mahalleler olarak öne çıkmıştır (Osmay 2006: 215-216). Özellikle Şeyh Mahallesi'nin sakinleri Muğla’nın ileri gelen ve en eski ailelerinden oluşmuştur. Hacı Şerifefendi, Hacıhamzalar, Gölcüklü, Hacıkadızade Süleyman Efendi, Hacı Çakırlar ve Baydurlar gibi köklü aileler, kentin tarihi geçim kaynakları durumunda olan tütün ve kereste ticareti ile meşgul olarak bu mahallede yaşamıştır (Türkeş ve Aksoy 1987'den aktaran Osmay 2006: 215). Camikebir Mahallesi ise kentin özgün niteliklerini günümüze dek muhafaza edebilmiş mahallelerden biridir (Aktüre 2006: 86).

Bugün değil belki ama geçmişte, mahallelerde insanlar gerek aynı mekânı paylaşma nedeniyle gerekse dini ya da mesleki ortaklıklar sonucunda dayanışma ve birlik içinde olmuşlardır. Çoğu zaman ekonomik ya da sosyal statüsü, gelir durumu farklı insanlar aynı mahalle içinde yaşamışlar ve tüm farklılıklara rağmen ortak bir paydada buluşabilmişlerdir (Aru 1998:12, Oktay 2001:46, Ortaylı 2009: 42, 51). Muğla için bunun en net örneği 1922 yılına dek Rum nüfusun ağırlıklı olduğu Saburhane semtinde yaşanmıştır (Aladağ 2004). Muğla’da da mahalleli için hastalık, doğum, ölüm, düğün gibi olaylar bir araya gelme, dayanı̧̧ma ve paylaşma vesilesi olmuştur. Böyle günlerde misafirin kimin için geldiği önemsizdir. Zira ev sahibi, mahallenin tüm sakinleridir. Eksik malzemeler el birliği ile tamamlanmakta, yatılı misafirler yakın komşularda kalabilmektedir. Mahallede yapılacak herhangi bir düğünden önce birlik beraberlik içinde düğün odunu hazırlanması, mahalledeki dayanışmaya örnek olarak gösterilebilir (Şahin 2004: 7-8,43; K1). Hemen tüm anlatılarda mahalleli olmanın "biz" olma algısı yarattığını görmek mümkündür. Örneğin, evin herhangi bir ihtiyacında ilk gidilen yer çarşı pazar değil komşudur (K2;K3). Evlerin gaz lambası ile aydınlatıldığı dönemlerde ${ }^{4}$ komşudan belki de en sık istenen şey gaz yağıdır. Yine kuru kahve, domates ya da soğan ödünç alınanlar arasındadır (Dereli 2008: 32; K4). Herhangi bir şeyin fazlası satılmayıp, komşuda eksik olabileceği düşünülerek mahalleliye dağıtılmıştır (K5). Dolayısıyla bir kent mekânı olarak mahalle, sakinlerine tamamlayan ve yakınlaştıran bir etki sunmuş; sosyal bir paylaşım ortamı yaratmıştır.

Mahalle sakinleri birbirlerine karşı son derece özenlidir. Örneğin henüz su şebekesinin yapılmadığı, suyun musluklardan akmadığ ${ }_{1}$ Cumhuriyet'in ilk 
yıllarında ${ }^{5}$ Muğla'da evden eve geçen ve "geriz" denilen suyolları vardır. Kent sakinleri kendi evlerinde küçük bir havuzcuğa biriken sudan ihtiyaçları kadar kullanırken aynı suyun kendilerinden sonraki evlere geçeceğini düşünerek suyu temiz tutmak için azami bir gayret göstermiştir (Tekeli 2006:165; Osmay 2006:218). O dönem çocukları belki de en fazla bu konuda tembihlenmiş; ellerini suya batırmamaları konusunda sıkı sıkı uyarılmıştır ya da soğuması için suya bırakılan karpuzlar öncesinde dışarıda iyice yıkanmıştır (Şahin 2004:6, Dereli 2008:27, K5). Mahalleli için suyun alt komşuya temiz bir şekilde ulaşması, onu kullanmaktan çok daha önceliklidir.

Geleneksel mahallede herkes birbirini tanımakta ve bu tanışıklı̆̆ın sonucunda birbirine kefil olmaktadır. Herhangi bir olayın sorumlusu ortaya çıkarılana kadar mahallede yaşayan herkes bundan sorumludur (Ergenç 1984:69,73,78). Muğla kentinde de ilişkiler öylesine sıcaktır ki, mahalle adeta büyük bir aile algısı oluşturmaktadır. Kız çocuk anneleri mahalle dışında bir yere gidileceği zaman evlatlarını mahallenin erkek çocuklarına emanet etmektedir. Mahalleli olma aynı zamanda güvende olma demektir. Öyle ki, hiçbir mahalle sakini kısa süreli ayrılmalarda evini kilitleme gereği duymamaktadır. (Şahin 2004:7, K5, K6).

Mahalleli olmanın birçok duyguyu da beraberinde getirdiği açıktır. Nitekim güven vermenin yanı sıra çocukluktan itibaren sosyal hayata uyum sağlama sürecinin ilk basamağını da oluşturur. Bu noktada mahalle komşuluk ilişkileri, mekânların tanınırlığı, esnafla kurulan diyaloglar sayesinde kendi yurdunda olma, aidiyet ve huzur hissi verir. Toplumsal ve kültürel düzeni bir yandan üretirken bir yandan da düzenler (Certeau vd. 2009: 35-37).

En yakındaki buluşma ve bir arada bulunma mekânı kentli için mahalle, mahalleli için sokaktır. Bu noktada kapı önü sohbetleri çevrede olup biteni öğrenme, "bizim evin dışında neler oluyor"u anlamanın en önemli ve en kestirme yoludur. Muğla'da bir zamanlar insanlar genellikle sabah ve akşamüstü saatleri olmak üzere günün iki farklı zamanında evlerinin önünde, Arnavut kaldırımlı ve çoğu çıkmaz olan sokakta komşuları ile oturup sohbet ederek bir kültür paylaşımında bulunmuşlardır. Sabahtan akşama mahallede, etrafta ne haber varsa, kim ne duymuşsa diğerleri ile paylaşmıştır. "Duydun mu filancanın kızı evleniyormuş, filancanın oğlu sünnet olacakmış, akşama şu yemeği yapacağım” türünden muhabbetler $(\mathrm{K} 5, \mathrm{~K} 6)$ insanın kendi dışındakiler hakkında bilgi ve fikir sahibi olmasını sağlamıştır. Komşuluk toplumsal bir doğrulama aracı iken dedikodu ve merak komşuluğu sürekli olarak besleyen bir etkiye sahiptir (Certeau vd. 2009: 41-42). Mahalleli haftanın belli akşamlarında da herhangi birinin evinde toplanmış ve ebeveynler bir arada 
bulunmanın tadını gündelik yaşamla ilgili sohbetler ederek; çocuklar ise isim şehir ya da sessiz sinema oynayarak çıkarmışlardır (Aladağ 2004:100,K5). 1970’li y1llarda televizyonun gündelik yaşama dâhil olmasından önce radyo, insanların hayatında çok büyük bir öneme sahiptir. Zira ülkede neler olup neler bitiyor, insanların kendi dünyaları dışında neler yaşanıyor gibi sorular radyo sayesinde cevap bulabilmiştir. Ancak o da her evde yoktur ve bu nedenle radyosu olmayanlar özellikle haber saatlerinde radyo bulunan evlerde toplanıp önce pür dikkat ajans haberlerini dinlemiş ve ardından dönemin meşhur sanatçılarının şarkıları eşliğinde sohbete koyulmuştur (Dereli 2008:29,K7).

"Hayat"a açılan müstakil evlerin ve çalınış şeklinden gelen misafirin cinsiyetinin anlaşıldığ kuzulu kapıların yerini beton yapıların aldığı günümüz Muğla'sında aynı mahallede yaşayan hatta aynı binada oturan insanların bile birbirleriyle "günaydın", "iyi akşamlar" dan öteye geçemeyen diyaloğu düşünüldüğünde geleneksel mahalledeki mekânların değişimi ve ilişkilerin dönüşümü ortaya çıkmaktadır.

\section{Cami}

Kapı önleri, ev gezmeleri bir yana herhangi bir mahallenin en merkezi bir arada olma mekânı aslında cami veya mescittir. Geleneksel mahalle yapısına bakıldığında cami, mescit, türbe gibi dini yapıların mahallenin merkezinde yer aldığ1 görülmektedir (Akgünlü 2008:8). Kent, belgelerin ifadesi ile "Cuma kilınur, bazar durur" yerdir (Öz 2005:59).

Muğla'nın en eski camii 1344 yılında Menteşe Beylerinden İbrahim Bey’in yaptırdığ1 ve Tabakhane yakınında bulunan Ulu Camidir (Ekinci 1985:20, Akçura 2006:246). "Emir Küçük” lakaplı Menteşeoğlu İbrahim Bey tarafından inşa ettirilen camii bu nedenle "Emir Küçük Camii" adıyla da anılmıştır. Zaman içinde caminin yıpranan kısımlarının Elvan Bey tarafından tamir ettirilmesi ise caminin "Elvan Bey Camii" ya da "Yeni Cami” adıyla tanınmas1na neden olmuştur (Uzunçarşılı 1929: 150, Akgünlü 2008:8). Evliya Çelebi söz konusu camiyi Eski Cami adıyla anmı̧̧, en fazla cemaate sahip cami olarak nitelemiştir (2011:105). Kurşunlu Camii ve Şeyh Camii, Ulu Camii’nden sonra inşa edilen diğer büyük camilerdir (Evliya Çelebi 2011: 106; Eroğlu 2011:137). 


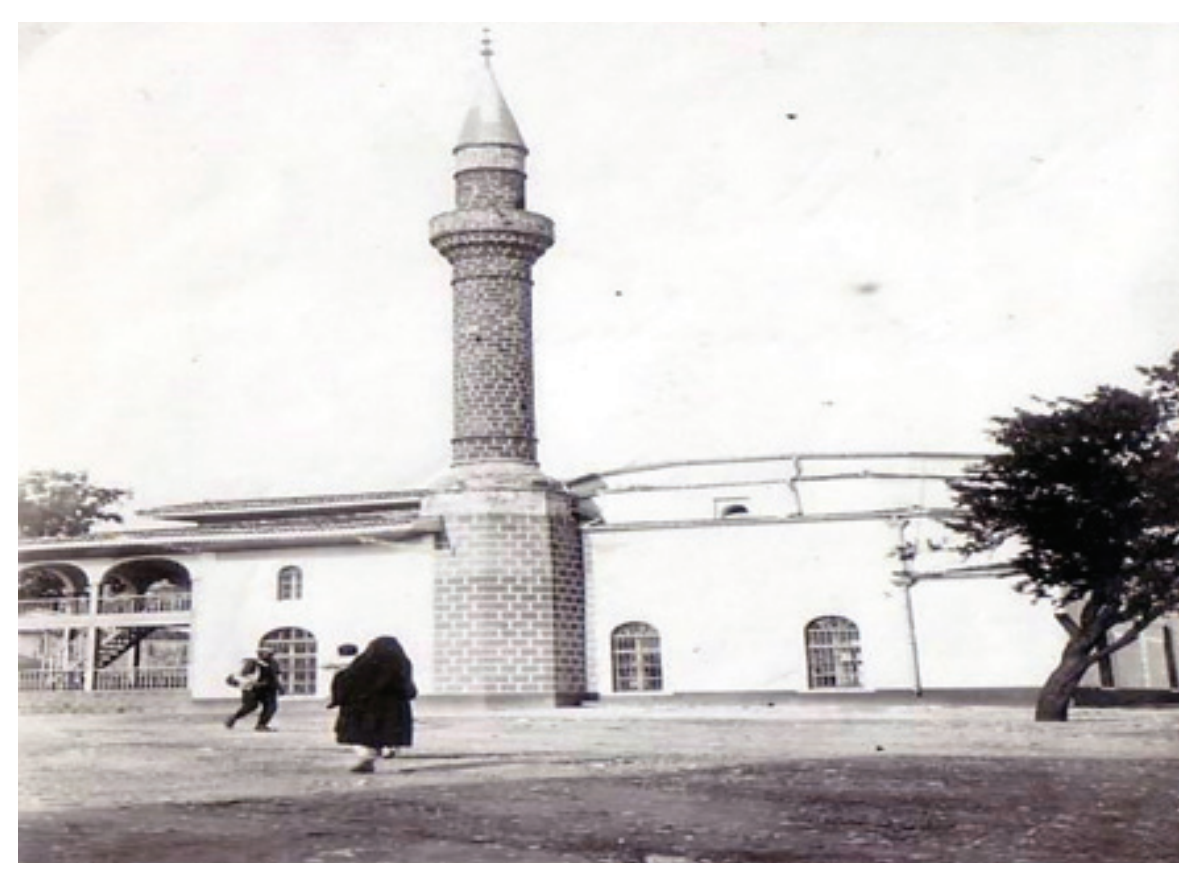

Fotoğraf: Kurşunlu Camii ${ }^{6}$

Mahallenin erkek bireyleri için camiye gitmek bir yandan kendini tanınır ve güvenilir kılmaktayken diğer yandan da konu komşu ile hasbihal etmenin kapılarını açmaktadır (Ergenç 1984:73). Namaz vakitleri yakınlaştığında cami etrafinda toplanıp sohbet etmek adeta bir kuraldır (K2). Dolayısıyla cami bir kent sakini için sadece bir ibadet mekânı olmanın ötesine geçmiş, bir iletişim mekânı olarak algılanmıştır. Kentlerin çekirdek kısmını oluşturan noktalar cami ve çarşı olmuş, tüm kent ve dolayısıyla yaşam bu çerçevede şekillenmiştir.

\section{Çarş1- Pazar}

Muğla Kenti için en merkezi bir arada olma mekânı cami çevresinde gelişen çarşı pazar olmuştur (Ekinci 1985:18). Kurşunlu Camii önü, Saatli Kule’ye doğru uzanan cadde, Kocahan'ın yanı sıra Gölcüklüoğlu ve Balcığlu Hanı çevreleri ile Belediye Hamamı'ndan Konakaltı'na doğru uzanan bölge Muğla Çarşısı'nı oluşturmuştur (Şahin 2004:36). Han, hamam, kahve, arasta, cami gibi yapılar çarşının en önemli unsurlarıdır. Gündelik yaşam için neye ihtiyaç duyulacaksa bu bölgededir. Evliya Çelebi'nin 17. yüzyıl gözlemlerine göre burada 200 kadar dükkân bulunmaktadır (2011:106). Dolayısıyla kadın-er- 
kek, genç-yaşl1, Müslim-Gayri Müslim, köylü-kentli tüm toplum bireylerinin yolu bir gün mutlaka buradan geçecektir. Toplumsal çeşitlilik ile doğru orantılı bir etkileşim yaşanması kaçınılmazdır. Kentin kalbinin attığı yer burasıdır. Her şeyden önce çarşıda esnaflık yapanlar arasında tam bir iş birliği ve güven ortamının varlığı söz konusudur. Nitekim Cuma namazına gidecek olan esnaf dükkânının kapısını kilitlemeye, dışarıdaki malzemeleri toplamaya gerek bile duymamakta, kısa süre içinde döneceğinin belirtisi olarak kapıs1nın önüne bir sandalye koyup gönül rahatllğı ile camiye gidebilmektedir. Mahalleli için nasıl sokakta kapı önü oturması yapılıyorsa, esnaflar arasında da aynı durumu görmek mümkündür. Sıkça dükkân önlerinde oturulup sohbet edilmektedir (Dereli 2008: 46, K2, K3).

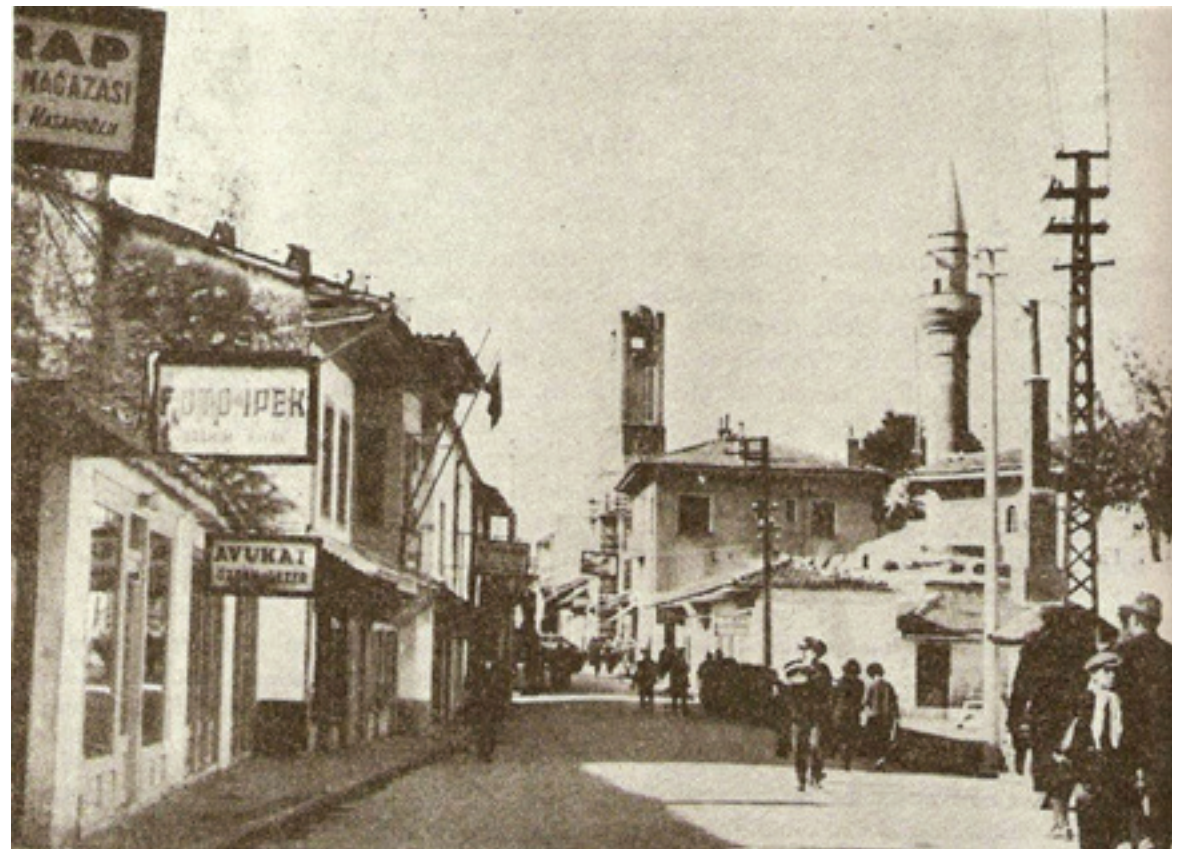

Fotoğraf: Eski Muğla Çarşısı'ndan Bir Görüntü

Kuruluşundan itibaren içinde bulunan yağhaneler ile önemli bir ticaret merkezi olan Yağcılar Hanı, peynir hali, kasaplar, demirci ve bakırcılar gibi ticaret ve zanaat erbabını bünyesinde barındıran Arasta'sı ile çarşı, hiç kuşkusuz kentin en önemli bir arada olma mekânıdır. Özellikle aynı iş ile meşgul olan meslek sahiplerinin aynı sokakta toplandığı Arasta, bu özelliği ile bir yandan çalı̧̧anlara yardımlaşma açısından kolaylık sunarken diğer yandan alıcılara da aradığını bulma, farklı seçenekleri bir arada görebilme noktasında fayda sağ- 
lamıştır (Dereli 2008:46). Dolayısıyla herhangi bir ihtiyacını gidermek için Arasta'ya gelen bir kent sakini aynı ihtiyaç nedeniyle orada bulunan başka biri ile karşılaşıp bu ortak noktadan başlayan derin sohbetlere dalabilmiştir.

Çarşıda sabit dükkânların yanı sıra seyyar satıcıların gelmesi ile pazar da kurulmuştur. Pazar Camii'ne bitişik bir noktada bulunan buğday, arpa, yulaf gibi malzemelerin satıldığı üç kapılı Zahire Pazarı Muğlalılar için ayrı bir öneme sahip olmuştur (Nevzat Kökçü 1998'den aktaran Akça 2002:191, Şahin 2004:36). Zahire Pazarı'na buğdaylar Tavas ve Denizli yöresinden develer ile taşınmıştır. Tahıl ihtiyacı olan kent sakinleri her seferinde sergileri tek tek gezmiş, satışa sunulan ürünleri avuçlarına alıp kalitesine onay verdikten sonra satıcı ile pazarlığa girişmiştir (Dereli 2008:39-41).

Pazarlar tarihin her döneminde üreten ile tüketeni bir araya getiren, alı̧ verişin sadece ürün ile sınırlı kalmadığı, kültürel etkileşimin de ağırlıklı olarak görüldüğü noktalardır. Nitekim pazarlar başta gıda malzemeleri olmak üzere çeşitli ihtiyaçların karşılanması amacına hizmet etmenin yanında bir yandan insanların sosyal ilişkiler kurmasını sağlamış, diğer yandan da merkezi yerlerin belirginleşmesine yol açmışlardır (Tuncel 2009:36). Dolayısıyla ekonomik olduğu kadar sosyal ve kültürel bir takım özellikleri de taşımaktadır. Pazarları satılan ürünlere, kuruldukları yerlere ya da kurulma zamanlarına göre gruplandırıp adlandırmak mümkündür. Bu noktada Muğla’da kurulan pazar geçmişten bugüne kurulma zamanına göre "Perşembe Pazarı" biçiminde adlandırılmıştır. Bu durum, zaman-mekân ilişkisi noktasında önem arz etmektedir (Tuncel 2009:40-42).

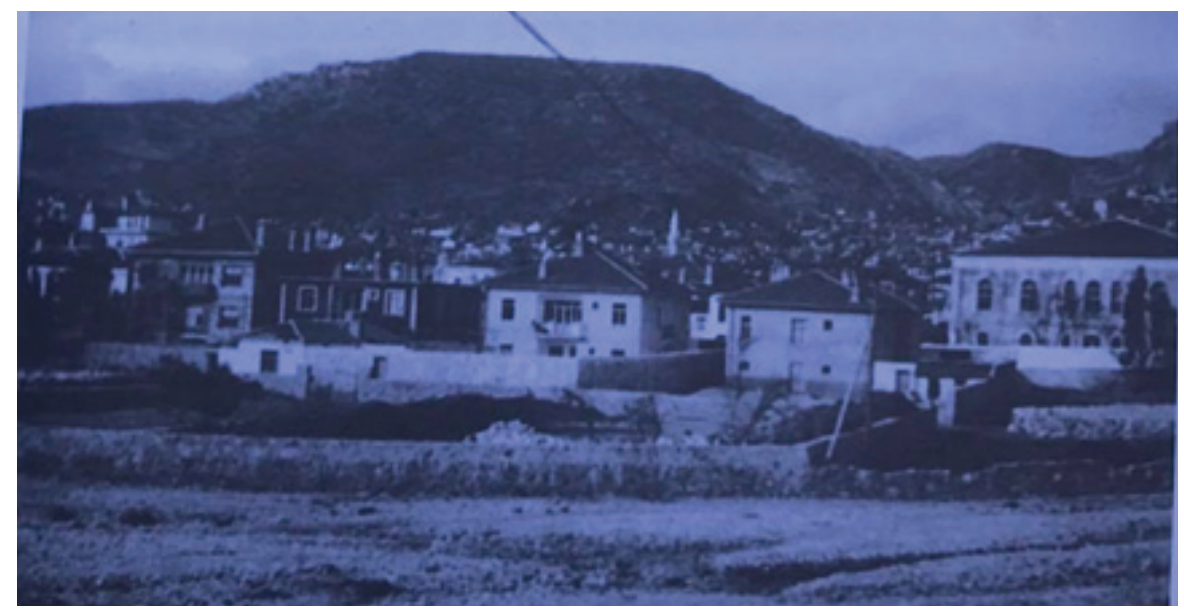

Fotoğraf: Perşembe Pazarı olarak düzenlenen Karamuğla Deresi yatağ1 (1956) 
En eski pazarlar ağırlıklı olarak 16. yüzyılın ikinci yarısına tarihlenmektedir. Muğla'da da bu dönemden itibaren pazaryerlerinin ticari faaliyetler açısından oldukça önemli bir yeri vardır (Faroqhi 2006:40,137,Tekeli 2006:67). Pazar yeri olarak ortaya çıkan mekânların bir kısmı zaman içinde önemini yitirip ortadan kalkabilmiş ya da başlangıçta pazar yeri bulunmayan kimi yerlerde ortaya çıkan ihtiyaç doğrultusunda zamanla pazarlar kurulabilmiştir (Tuncel 2009:36). Perşembe Pazarı'nın kurulduğu gün sabit kalırken kurulduğu mekân zaman içinde değişiklik göstermiştir. Perşembe Pazarı, Cumhuriyet'in ilk yıllarında Kurşunlu Camii çevresinde kurulurken ${ }^{7} 1960$ 'lı yıllarda Devlet Hastanesi'nin alt tarafında bulunan boşluk alana taşınmıştır. Daha öncesinde açık olan Karamuğla Deresi'nin üzerinin zaman içinde örtülmesi ile 1970'li yıllarda pazar yeri günümüzde de bulunduğu alanda, derenin üstünde kurulmaya başlamıştır (Kökçü 1998 ve Günsan 1998'den aktaran Akça 2002:191, $\mathrm{K} 3)$.

Muğla'nın meşhur Perşembe Pazarı için hazırlık, çarşamba gecesinden başlar. Kurşunlu Camii'nin çevresine kurulan pazarda meyve, sebze, çerez gibi çeşitli gıda maddelerinin yanı sıra oduncular bulunmaktadır. Eşeklerine, katırlarına yükledikleri odunları satma umuduyla gelmişlerdir ve aslında oduncular bir zamanlar Muğla'sında sadece Perşembe pazarlarının değil çarşının da daimi satıcılarıdır (Şahin 2004:33-34). Evler, hamamlar, ekmek firınları ve elbette kireç ocakları hep odunla 1sınmakta; günde 600-700 hayvanın dağ köylerinden çektiği odunlar kentte kilo ile satılmaktadır. O kadar ki, oduna duyulan büyük ihtiyaç nalbantlık mesleğine de altın çağını yaşatmıştır (Şahin 2004:34, Küçem 2015'den aktaran Türköz 2018:91).

Pazara gitmek Muğla sakinleri için geçmişten günümüze hemen her devirde önemli bir etkinliktir. Perşembe Pazarı kent sakinleri ve hatta yakın çevre için aslında hayatın renklerinden biridir. Tanıdıklar ile karşılaşarak ayaküstü konuşabilme olanağ1 vermesi önemlidir (K5). "Gitmişken geçen hafta gördüğüm Mehmet çavuşun kızını da görür müyüm” gibi düşünceler aklın hep bir yerindedir (K4). Üstelik bu tanıdıklar içine artık yıllardır aynı yere tezgâh açıp satı̧ yapan pazar esnafı da dâhil olmuş durumdadır. Bu yönüyle pazar yerleri sadece evin ihtiyacını karşılamak için gelinen bir yer olmanın ötesinde kendi dışındakiler ile iletişim kurma, dış çevreden haber alma yeri, bir kültürel aktarım mekânıdır. Sosyal ve ekonomik açıdan farklı özelliklere sahip insanların aynı anda bir arada bulunduğu yerler olması açısından tam bir etkileşim yaşanabilmesine olanak tanır. Buradaki sesler, renkler ve kokular yerel kültürün izlerini taşır (Çalışkan 2007:76) dahası insanlara bir aidiyet duygu- 
su hissettirir. Örneğin; geçmişi çok eskiye dayanan ipek böcekçiliği Muğla’da Cumhuriyet'in ilk yıllarından 1970'lere kadarki dönemde de geleneksel bir aile uğraşı olarak varlığını sürdürmüştür (Çolak 2002: 4). Dut ağacı, evlerin "hayat"larında olmazsa olmazdır. Bu dönemde Perşembe Pazarı'na ne zaman gitseniz "kuş tohumu... kuş tohumu" diye bir ses çalınmıştır kulağınıza. İpek böceği yetiştirmeye "kuş tutma" diyen Muğlalı için kuş tohumu ipek böceği yumurtasıdır ve belirtildiği üzere Perşembe Pazarı'nın en tanıdık sesidir (Şahin 2004:14, K4). Kulağa gelen, gürültü değil tam tersine hoş bir melodidir. Kent, haftanın en hareketli, en canlı, en kalabalık gününü yaşamaktadır. "Pazara gitmek" o gün yapılacak en öncelikli ve belki de tek iştir. Perşembe günleri pazara ayrılmış, haftalık rutin buna göre düzenlenmiştir. Sebze, meyve ama ille de haber alınacaktır. Hoş sohbet edilecek, hal hatır sorulacaktır. Pazar çevre köylerden gelenler için kuşkusuz çok daha anlamlıdır. İhtiyaçlar giderilecek, kentte yaşayan eş dost görülecek, Muğla simidi yenilmeden de dönülmeyecektir.

Perşembe Pazarı, Muğlalı kadınlar için ayrı bir anlama da sahiptir. Zira pazarda kadınların kendi el emeği ile yaptıkları ürünleri, örme ve dokumaları sergileyip satı̧̧ını yaptıkları bir kısım da bulunmakta ve halk tarafından kadınlar pazarı olarak adlandırılmaktadır (Kökçü 1998'den aktaran Akça 2002:191, K2). Bu uygulama kaybolmadan günümüze kadar korunmuştur. Perşembe Pazarı'nın Muğla kent sakinlerinin hayatındaki önemini günümüzde de sürdürdügünü söylemek yanlış olmayacaktır.

\section{Kahvehane}

Tarihi süreç içinde çeşitli işlevlere sahip olmuş bir mekân konumundaki kahvehanelerin 16. yüzyıldan itibaren gündelik yaşama dâhil olması ile yaşam, adeta renklenmiştir (Peçevi 1981:258, Yaşar 2005:239). Kent sakinleri ev dışında ibadet merkezi cami ve ticaret merkezi çarşıyı sosyal alan olarak kullanırken kahvehaneler yeni bir etkileşim mekânı olarak ortaya çıkmıştır. Cami ve kahvehane, geleneksel mahallede bilgi alış verişinin ve kamuoyunun oluştuğu merkezlerdir (Ortaylı 2009: 42) ve zaten kahvehanelerin kurulum aşamaları da cami ile ilişkilidir. Namaz vaktini beklemek için bir araya gelen mahalle sakinlerinin oturdukları yerler zamanla kahvehaneye dönüşmüştür. Kahvehaneler, aynı yerel kültüre ait ancak farklı meşguliyetleri olan insanların günün belli saatlerinde bir araya geldikleri önemli bir buluşma mekânıdır. Çoğu zaman iş hayatıyla özel hayat arasında bir uyum, denge sürecinin alanıdır (Certeau vd. 2009: 48). Önemli bir haber alma ve kültür üretme merkezi olan kahvehaneler bu özellikleri nedeniyle özellikle Osmanlı döneminde sık sık yasaklanmıştır. Kent bireyleri için sosyalleşme alanı iken yönetim tarafından fitne merkezi olarak algılanmıştır. 
Toplumun bir arada bulunma mekânları içerisinde kahvehaneler ilk bakışta cinsiyeti net şekilde belirlenmiş ve kadınları dışarıda bırakmış bir mekân olarak görülebilir (Arık 2009:169,178; Certeau vd. 2009: 47). Ancak bu noktada günümüzde Muğla’nın geleneksel adetleri, çiçek başlı kadınları ile ünlü Çomakdağ Köyü’nde bir kahvehanenin işletmecisinin kadın olduğunu (K8), kahvehanelerin cinsiyetlendirilmiş bir mekân olma geleneğini kıran bir örnek olarak belirtmek gerekir.

Toplumun erkek bireylerinin sinemaya gidemedikleri akşam eğer komşularına akşam gezmesine de gitmeyeceklerse yaptıkları iş, kahvehaneye gitmektir. Arkadaşları ile bir arada bulunup sohbet edecek, vakit geçireceklerdir. Gündelik kaygılar, can sıkan dertler, umutla beklenen haberler ya da mühim devlet meseleleri hep kahvehane sohbetlerinin konularını oluşturmuştur. Her şey konuşulmuş ve paylaşılmıştır. Akıldan geçenler, sadece kendi kendine konuşulup işin içinden çıkılamayan nice durumlar burada çözüme kavuşturulmuştur (K2). Kahvehaneler bu şekilde sosyal ihtiyaçları karşılamanın yanı sıra işsizler için de bir arada olma ve iş bulma noktalarıdır. İş bulmak isteyenler sabahın erken saatlerinde buralara gelmiş ve insan gücüne ihtiyacı olanlar tarafından günlük işçi taleplerinin karşılandığı yerler olmuştur (K7). Ramazan geceleri iftardan sonra kahveye çıkmak ve sahura kadar arkadaşlar ile orada vakit geçirmek Muğlalılar için yakın geçmişe ait güzel bir anıdır (K2).

Muğla'da kahvehaneler ile çınar ağaçları (Muğlalılar çınar ağacına kavak der) (Şahin 2004:59, K1) özdeşleşmiş gibidir. Çaylar ulu çınar ağaçlarının gölgesinde yudumlanır. Bir zamanlar Muğla’sında kahvehane dendiğinde elbette mahalle kahvehaneleri, belki pazar yerinde bulunan ve "Bayram'ın Kahvesi" diye anılan mekân (K9) ama hepsinden de çok bilmem kaç yüzyıllık çınar ağaçlarının gölgesindeki yayla kahveleri akla gelmektedir. Yazlık ve kışlık bölümleri bulunan bu kahvelerin hemen yanında bakkal, terzi, kasap gibi çeşitli iş alanlarına ait dükkânlar ve elbette camii bulunur (Tekeli 2006:166, 773). Kahve etrafindaki dükkânlara ilave olarak bu mekânlarda kimi zaman seyyar satıcıların da gelmesi ile "kabageç" olarak adlandırılan küçük pazarlar kurulduğu da olmuştur (Şahin 2004:60,86,88, Dereli 2008: 76, K5). Zaman zaman kahvelerin önleri yayla sakinlerinin toplanıp keyifle izlediği pehlivan güreşlerine mekân oluşturmuştur (Şahin 2004:85, K4). Saburhane de kahvehane kültürü ile tanınan bir diğer semttir. Rumların yaşadığ1 Cumhuriyet öncesi dönemde meyhanelere ev sahipliği yapan semt meydanı (Tekeli 2006: 165) sonrasında kahvehaneler ile çevrili bir hal almıştır. Genel olarak bakıldığında kahvehaneler kentin erkek sakinleri için yarattığ̣ sosyalliği günümüzde de korumaktadır (K1). 


\section{Sinema}

Sinema mekân olarak film izlenen yer olmanın çok ötesinde anlamlara sahiptir. Her şeyden önce sosyal ilişkilerin gelişmesine vesile olan bir iletişim mekânıdır. Sinemada seyretme eyleminin yanı sıra yenilir-içilir, sohbet edilir, "diğerlerinden" haberdar olunur, birkaç saatliğine de olsa gündelik sorunlar unutulup tatlı hayallere dalınır (Öztürk 2013: 21, Akbulut 2014:5). Sinemaya gitmek aslına bakılırsa; hazırlık sürecinden tutun da eve geri dönüşe kadar bu deneyimi yaşayan herkes için "biz olma" duygusu yaratmaktadır. Zira çok yönlü ve ortak bir deneyim paylaşılmaktadır. Ortak bir amaç etrafında toplanilmaktadır (Akbulut 2014:6).

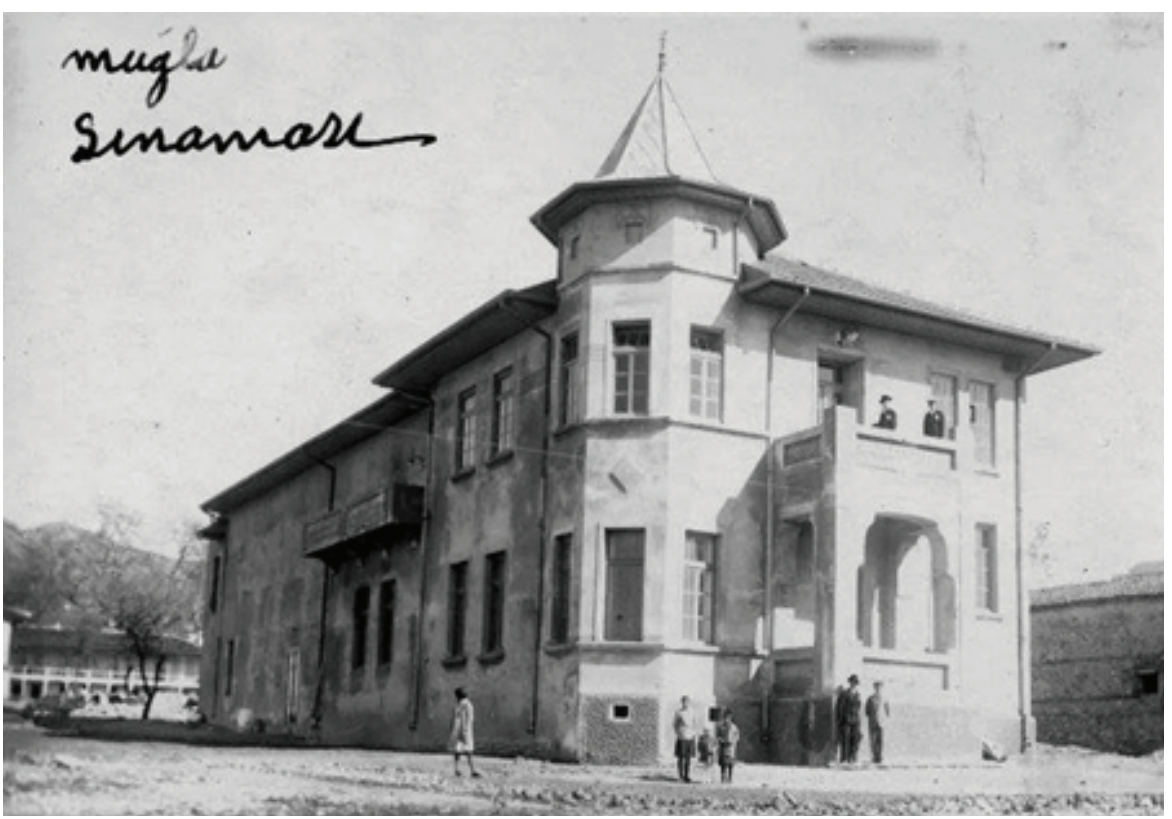

Fotoğraf: Muğla Kulüp sineması

Muğla’da ilk sinema gösterimi 1921 yılında Koca Mustafa Efendi Okulu'nun arkasında bulunan bir binada Baha Bey tarafından başlamıştır. 1930 yılına gelindiğinde Kurşunlu Camii'nin ön taraflarındaki bir binada Baki Soydan tarafından Kulüp Sineması açılmış ve bu adla 1970 yılına kadar hizmet vermiştir (Topaloğlu 1998 ve Eren 1999'dan aktaran Akça 2002:152). 1970'li yıllarda bu sinema belediyeye geçerek Belediye Sineması adıyla anılmaya başlamıştır (Muğla 12 Aralık 1952, Akça 2002:152). 1963 yılında günümüzde de hala aynı adla hizmet vermekte olan Zeybek Sineması açılmış, burada film gösterimlerinin yanı sıra çeşitli tiyatro oyunları da sergilenmiştir (Zey- 
bek 1998'den aktaran Akça 2002:152-153).

Sinema kent sakinleri için sadece bir seyir mekânı olmanın çok ötesindedir; kendini gösterme ve kendi dişındakileri görme yeridir (K3). Nice bakışmaya, göz süzmeye, karş1lıklı gülüşmeye sahne olmuştur. Özellikle genç erkeklerin film sonlarında beğendikleri kıza bakabilmek için sinema çıkışında insandan bir koridor oluşturmaları ya da pembe zarf içindeki mektupların ellere tutuşturulması sık karş1laşılan bir durumdur (K10).

Sinema, insanları bir araya getirmekle kalmayıp onların birbirleri ile iletişim kurabilmeleri için çok fazla malzeme sunar. Karşılaşıldığında sohbet edilecek, hal hatır sorulacaktır. Film izlenirken ortak tepkiler verilecek; sonunda filmin kritiği yapılacak ve oyuncular hakkında konuşulacaktır. Çoğu insan belki de ilk sinema deneyiminde izlediklerinin gerçek olduğu yanılgısına kapılmış; örneğin filmdeki atların kendi üzerine geldiğini sanıp bağırmıştır (Caner'den aktaran Aladağ 2004:88). Bu ve benzeri olaylar o akşamın ve belki de ertesi günün konuşulacakları arasındadır. Kapalı sinema mekânlarındaki sessizliğin aksine açık sinemalarda tam bir rahatlık ve olduğu gibilik hâkimdir. Tepkiler bastırılmaz. Gülünecekse gülünür, takdir edilecekse birden bire "helal olsun” sesleri yükselebilir ya da tam tersi... O an ne hissediliyorsa her şey ortadadır. Örneğin özellikle Battal Gazi filmlerinde izleyiciler kendilerini tutamayıp tepkilerini hep yüksek sesle vermiş, salondan birden bire "Vur Battal Gazi... Vur” tarzında seslerin yükseldiği çok olmuştur (Öztürk 2013:22, K10). Kapalı sinema salonlarında localar, balkonlar varken yazlık sinema daha eşitlikçi bir yapı sergilemiştir (K7, K10).

Sinema o kadar zaruri bir ihtiyaçtır ki, gezici sinema makinası Muğla'nın hizmetleri ile bugün dahi anılan meşhur valisi Recai Güreli döneminde 1936-1938 yılları arasında getirilmiş ve kullanılmaya başlanmıştır (Öncüer 1998'den aktaran Akça 2002:152). İnsanların medeni ihtiyaçlarından biri olarak görülen sinemanın, köylülerin gelişimine katkı sunacağı düşünülerek seyyar ve sesli sinema köylere sıra ile gönderilmiştir (Eroğlu 2011:136). Yine Muğla'da kentli, 1970'lere kadar canlı bir biçimde yaşayan yayla hayatına geçtiğinde sinema da onlarla birlikte yaylaya göçmüş; seyyar sinemalar bu sefer yaylada gösterime girmiştir. Kalasların ve tahta kasaların üzerine oturarak izlenen filmlere evde karpuz çekirdeklerinin kavrulması ile oluşturulan çerezler ve seyyar satıcılardan alınan gazozlar eşlik etmiştir. İnsanların bir araya toplandıkları ev gezmelerinde çocukların vakit geçirmek için sessiz sinema oynamaları (K5) sinemanın kent sakinleri için önemini ve onların yaşamına ne denli girdiğini göstermesi açısından önemlidir. 
Sinema stres atma, sosyalleşme, haber alma, tanışma, buluşma, etkileşim, hayal kurma gibi çok çeşitli amaçlara hizmet etmiştir. Sinema herkese açık bir mekân olmasına rağmen bazıları için sinemaya gitmek belki de hayatlarının en lüks etkinliğidir. Zira ödenecek bir bedel vardır ve bilet parası bunun sadece en somut olanıdır. Ancak iş kılık kıyafetten başlamaktadır. Sırf akşama sinemaya gideceği için öncesinde kuaföre gidip saçını yaptıranlar olmuştur (K10). Film izlerken tüketmek üzere kuruyemiş almak gerekmektedir. ${ }^{8}$ Ailecek gidilen bir mekân olduğu da hesaba katılırsa bütçeyi etkileyen bir özelliğe sahip olduğu düşünülebilir. İnsanlar belki de gidecekleri filmin hayalini kurarak tüm ay para biriktirmektedir. Hatta bazı kent sakinleri sinemanın maliyetli bir etkinlik olmasından dolayı gidemediklerini belirtmektedir (K6). Bu durumda sinema salonunu kullanmak belli bir çaba ve emeğin sonucunda mümkün olabilmektedir. Giyinip kuşanma, yol yürüme, bilet ve kuruyemiş parası ödeme gibi bedelleri vardır. Insanların zaman zaman sinemaya kaçak girmek, bir bilete iki kişi girmek gibi yollara başvurması, bu mekânın ve eylemin onların yaşamındaki anlamını göstermesi açısından önemlidir (Öztürk 2013:22).

Muğla'da 1960'lı yllarda kent sakinlerinin sadece sinemalara değil bunun yanı sıra tiyatroya da ilgi duydukları hatta bu noktada sanatsever olarak nitelendikleri anlaşılmaktadır. Sürekli çalışan bir tiyatro olmasa da yaklaşık olarak ayda bir dışarıdan gelen tiyatro topluluklarının oyunlarının izlenmesi söz konusudur. Ayrıca ilk ve orta dereceli okullarda düzenlenen çeşitli etkinlikler de yine kent sakinlerinin bir arada olma vesilesidir (1967 İl Y 1llı̆̆1:254, 305).

\section{Park}

Muğla kent sakini için park dediğinizde bir tebessümle birlikte hatıra gelen 1960'lı yılların Yalabuk Parkı'dır. Hiç istisnasız görüşme yapılan tüm kent sakinlerinin belleğinde hoş bir anı olarak yerini almış ve "süs yolu" ile adeta özdeşleşmiştir.

Anlatılara göre Muğla’da insanlar özellikle akşamüstü saatlerinde anıttan Akyol Camii'ne kadar uzanan güzergâhta üçerli beşerli gruplar halinde yan yana kol kola bir aşağı bir yukarı yürüyüş yapmaktan büyük keyif almıştır (K5). Yolun süs yolu biçiminde adlandırılması, burada yürüyüş yapan insanların kılık kıyafetlerinden tutun da saçına makyajına kadar dış görünümünün tüm detaylarına fazlaca özen göstermesi ile alakalıdır. Bu durumda kent sakinleri için yapılan, basit bir akşamüstü yürüyüşü değildir. Öncesinde gerçekleştirilen bir hazırlanma süreci vardır (K3). Sözü edilen süs yolu, sadece yürüyüş yolu olmanın ötesinde insanların kendini gösterdiği, birbirini gördüğü, ba- 
kışma ve tanışma mekânı olma özelliğine sahiptir. Öyle ki, evleneceği kızı süs yolunda seçen birçok Muğla kent sakini bulunmaktadır (K3, K7).

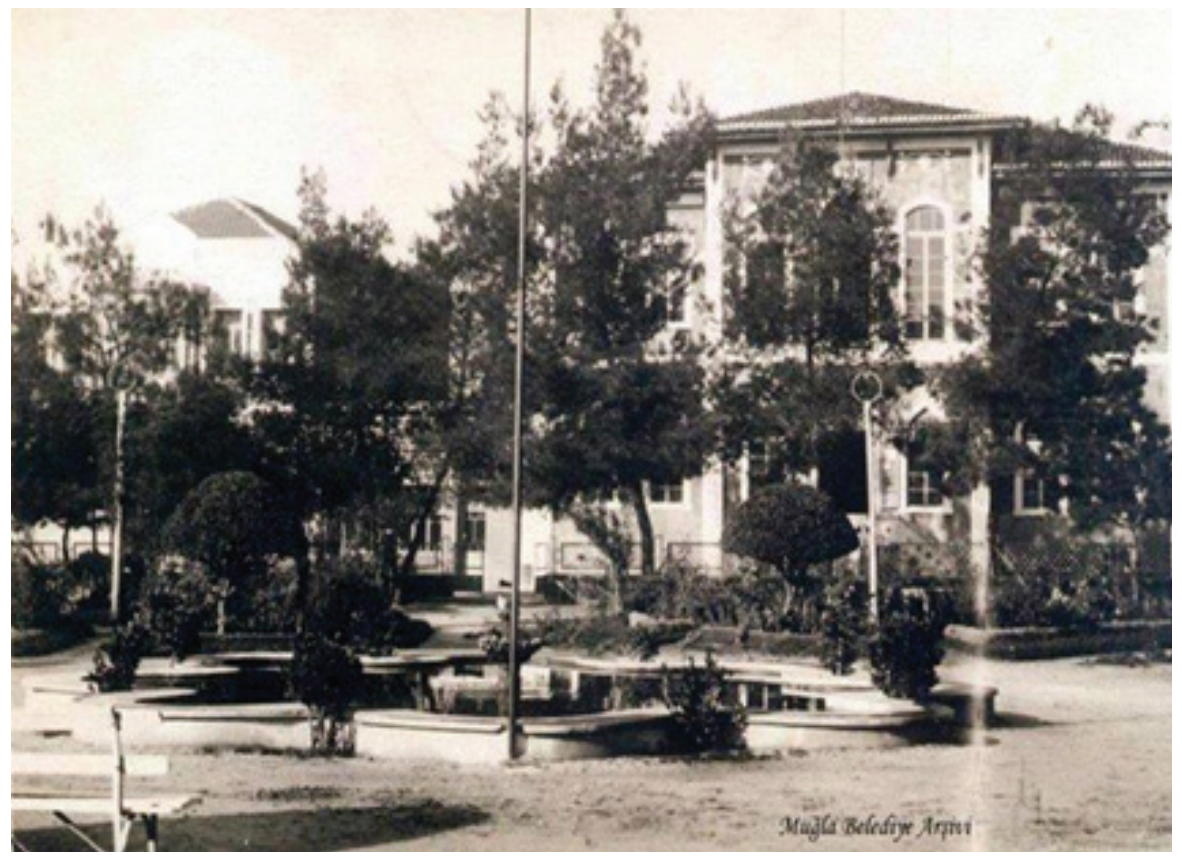

Fotoğraf: Belediye Parkı

Süs yolundaki yürüyüşün ardından ya da tam tersi öncesinde gidilecek mekân, Yalabuk Parkı'dır (günümüzde Menteşe Belediye binasının önünde yer alan park). İşletmecisi olan Mustafa Yalabuk adlı kişiye atfen bu adı almıştır (K9, K11). Yalabuk'un herhangi bir makine kullanmadan dağdan getirilen kar kütleleri ile yaptığı dondurmaların tadı bugün bile damaklardadır. Görüşme yapılan kent sakinleri Belediye parkının Yalabuk Parkı olduğu dönemlerde bu mekânın iğne atsanız yere düşmeyecek biçimde kalabalık olduğunu hatta kimi zaman önceden rezervasyon yaptırıldığını anlatmaktadır (K3, K5, K9). Diğer kent mekânlarına benzer şekilde bu park ta aslında insanların kendini diğerlerine gösterme ya da kendi dışındakileri görme ihtiyacı ve isteğine cevap vermiştir. Nitekim kapıdan bir aile girdiğinde tüm gözler o ailenin üstüne döner ne giydiğinden başlanarak saçı başı, hali tavrı tam bir gözlem altına alınır (K4). Dolayısıyla dondurmanın nefis tadı ve hava almak amacı bir yana parka gitmek kendini görünür kılmak amacına da hizmet etmiştir. 


\section{SONUÇ}

Mekân ve insan arasındaki ilişki, kent tarihlerinin özellikle de kentin kültür tarihinin aydınlatılması noktasında büyük bir kıymete sahiptir. Zira gündelik hayatın tüm detaylarının yaşandığı kentsel mekânlar bir yandan kent karakterini ortaya koyan bir özellik taşırken diğer yandan mekânı paylaşan insanlar için de bir kimlik üretmektedir. Başlangıçta bizzat insanlar tarafından oluşturulmuş mekânlar zaman içinde onların farklı tecrübelerine ev sahipliği yaparak anılarda yer almakta ve bu doğrultuda bir anlam kazanmaktadır. Söz konusu yaşanmışlıklar insanın mekânla kurduğu ilişkiyi güçlendirmekte ve bir aidiyet duygusu yaratmaktadır. Bu çalışma kent mekânlarının kültür üretme ve paylaşma noktasındaki rolünü ele almış; kentin kültür tarihine Muğla kent merkezi örneğinde ve insan-mekân ilişkisi üzerinden bakmıştır. Yazı1ı ve sözlü kaynaklardan edinilen bilgiler doğrultusunda mekânların, insanların iletişim kurma ihtiyacına cevap verdiği, aidiyet duygusunu güçlendirdiği ve yerel kültürün aktarım noktaları olduğu anlaşılmıştır.

İncelenen dönemde kent sakinleri özellikle sokak ve mahalle kültürü içinde adeta büyük bir ailenin fertleri gibi sıcak ve içten ilişkiler kurmuş, yardımlaşma ve güven içinde yaşamıştır. Bireyler özel ve mahrem olarak nitelenen ev hayatı dışında toplumun diğer fertleri ile sürekli bir karşılaşma ve bir arada olma durumu içindedir ve aslında buna muhtaçtır da. Zira insan doğası gereği haber alma, kendini gösterme, topluma onaylatma, diğerleriyle ilişki içinde olma gibi eylemlere ihtiyaç duyar. Teknolojik imkânların yeterince gelişmediği, iletişim olanaklarının çok kısıtlı olduğu dönemlerde mahalle, kahvehane sinema, park gibi mekânlar insanların bir aradalıklarını mümkün ve sürekli hale getiren buluşma yerleri olarak öne çıkmıştır. Buralar bilginin üretildiği, yayıldığı ve paylaşıldığı noktalar olmuş; kültürel aktarım mekânları haline gelmiştir. Bu açıdan bakıldığında söz konusu mekânların topluluk bağlarını güçlendirdiği, aidiyet duygusunu geliştirdiği ve ortak deneyimler yoluyla "biz olma" duygusu yaratarak kaynaştırıcı bir tavra sahip olduğunu söylemek mümkündür. Ne var ki, tarihi süreç içinde mekânsal bir değişim yaşandığ̣, insan ilişkileri ve gündelik yaşamda meydana gelen dönüşümün de bu değişimle ilişkisi olduğu açıktır. Günümüzde Perşembe Pazarı ve kahvehane dışındaki mekânların insan ilişkileri açısından ifade ettiği anlam oldukça değişmiş ve etkisini yitirmiş gözükmektedir. 


\section{Sonnotlar}

1 Nitekim yapılan sözlü görüşmeler sırasında bu, net biçimde görülmüştür. İnsanlar olaya “yaşadık işte... ama bunlar senin ne işine yarar ki” biçiminde yaklaşmaktadır. Hamdi Yumuk ile 2.11. 2018 tarihinde yapılan görüşme.

2 Görür görmez neden ve kim tarafından dikildiğini merak edeceğiniz meydanındaki Mimar Sinan Heykeli, sokağa açılan pencereleriyle geleneksel Muğla evlerinden ilk bakışta ayrılan taş evleri, kim bilir nelere tanıklık etmiş tarihi çınar ağacının gölgesindeki meydanı, hamamları, kilise harabeleri, eski şaraphane binası ve kahvehane kültürü ile Saburhane bir açık hava müzesi gibidir. Bir arada yaşamanın getirdiği kültürel zenginliği yansıtmaktadır.

3 Makalede kullanılan haritaların düzenlemeleri Gizem Çorbacıoğlu tarafindan yapılmıştır.

4 Muğla’da elektrik ilk olarak Cumhuriyet'in ilk yıllarında sadece çarşıya ve hükümete 110 voltluk olarak Zorbazzade Ragıp Bey'in sahibi olduğu kereste fabrikasından verilmiş; 1930 yılında Ali Adnan İzmirli tarafından elektrik fabrikası kurulmuştur. Bu fabrika 1937 yılında belediye tarafindan alınarak geliştirilmiştir. H. Nuri Öncüer görüşmesinden; Dâhiliye Vekâleti Mahalli İdareler: Belediyeler, İstanbul 1933, s. 752753’ten aktaran İlhan Tekeli, “1923-1950 Döneminde Muğla’da Olan Gelişmeler”, Tarih İçinde Muğla, (Der. İlhan Tekeli), Muğla Belediyesi Yayınları-1 (2. Baskı), Muğla 2006, s. 114-187, s. 164.

5 Kente temiz ve düzenli olarak su getirme amacına yönelik ilk ciddi girişim 1936 yılında gerçekleşmiştir. 1941 yılına gelindiğinde iki su deposu tamamlanmış; 24 saatte 2 bin ton su kapasiteli su şebekesi oluşturulmuştur. Bkz. İlhan Tekeli, "1923-1950 Döneminde Muğla’da Olan Gelişmeler”, Tarih İçinde Muğla (Der. İlhan Tekeli), Muğla Belediyesi Yayınları-1, (2. Baskı), Muğla 2006, 14-187, s. 164-165.

6 Makalede yer alan tüm fotoğraflar "Eski Muğla Fotoğrafları" isimli dijital sayfadan alınmı̧stır: https://www.facebook.com/eskimugla/ (Erişim Tarihi: 15.02 .2021$)$

7 Pazarların camii çevresine kurulması bir yandan ibadet için camiye gelen kalabalığın alış verişi arttıracağı diğer yandan da pazara ürün satma amacı ile gelen köylülerin en azından bir öğle namazını büyük bir camide kılmasının sağlanması gibi sebepler ile ilişkilendirilmiştir. Bkz. 
Doğan Kuban, "Anadolu Türk Şehri Tarihi Gelişmesi, Sosyal ve Fiziki Özellikleri Üzerinde Bazı Gelişmeler, Vakıflar Dergisi, Sayı VII, Baha Matbaas1, İstanbul 1968, s. 53-73, s. 71.

8 Bugün akla ilk gelen mısır olsa da geçmiş dönemlerde sinemalarda nohut leblebi, nane şekeri gazoz tarzından yiyecek ve içecekler tüketilmiştir. (K2, K10). 


\section{KAYNAKLAR}

Akbulut, Hasan (Ağustos 2014). "Sinemaya Gitmek ve Seyir: Bir Sözlü Tarih Çalışması”, Elektronik Mesleki Gelişim ve Araştırma Dergisi (EJOIR), C. 2, Özel Sayı, s. 1-16.

Akça, Bayram (2002). Sosyal-Siyasal ve Ekonomik Yönüyle Muğla (19231960), Ankara: Atatürk Araştırma Merkezi.

Akçura, Necva (2006). "Muğla’da Geleceğe Yönelik Çabalar: Tarihi Çevre Koruması”, Tarih İ̧̧inde Muğla (Der. İlhan Tekeli) Muğla: Muğla Belediyesi Yayınlari, 2. Baskı, s. 240-268.

Akgünlü, Volkan Levent 2008. Temettuat Kayıtlarına Göre XIX. Yüzyılın Ortalarında Muğla'nın Sosyo-Ekonomik Yapısı (Edt. Ahmet Yiğit), Muğla: Muğla Mermerciler Derneği Yayınları.

Aktüre, Sevgi (2006). “19. Yüzyılda Muğla”, Tarih İ̧̨inde Muğla (Der. İlhan Tekeli) Muğla: Muğla Belediyesi Yayınları, 2. Baskı, s. 34-113.

Aladağ, Ertuğrul (2004). Kentimin Öyküsü Muğla'da Rum İzleri, İstanbul: Belge Yayınları.

Arık, Hülya (2009). "Kahvehanede Erkek Olmak: Kamusal Alanda Erkek Egemenliğin Antropolojisi”, Cins Cins Mekân (Der. Ayten Alkan), İstanbul: Varlık Yayınları, s.168-201.

Aru, Kemal Ahmet (1998). Türk Kenti, İstanbul: Yap1 Endüstri Merkezi Yayınları.

Aytaç, Ömer (2007). “Kent Mekânlarının Sosyo-Kültürel Coğrafyası”, Fırat Üniversitesi Sosyal Bilimler Dergisi, C. 17, S. 2, s. 199-226.

Binay Berivan, Ümit Tatlıcan (2018). "Sembolik Etkileşimcilik ve Gündelik Hayatın Keşfi”, Gündelik Hayat Sosyolojisi Temalar Sorunsallar ve Güzergâblar (Edt. Ali Esgin, Güney Çeğin), Ankara: Phoenix, s. 147-190.

Caunce, S. (2017. Sözlü Tarih ve Yerel Tariḩ̧i (Çev. Can, B. B. Yalçınkaya, A), İstanbul: Tarih Vakfi Yurt Yayınları.

Certeau M. De, L. Gıard, P. Mayol (2009). Gündelik Hayatın Keş̧i II, (Çev. Çağrı Eroğlu, Erkan Ataçay) Ankara: Dost Kitabevi Yayınları.

Çalışkan, Vedat (2007). “Kentsel Mekân Kullanımındaki Farklılıklar Üzerine Bir Yaklaşım: Bursa ve Çanakkale'nin Periyodik (Haftalık) Pazarlarından Örnekler”, Doğu Coğrafya Dergisi, S. 18, s. 49-78. 
Çolak, Melek (2002). "Cumhuriyet Döneminde Muğla'da İpek Böcekçiliği ve İpekli Dokumacilık (1923-1970)”, Muğla Üniversitesi Sosyal Bilimler Enstitüsü Dergisi, S. 8, s. 1-16.

Danacıoğlu, Esra (2001). Geçmişin İzleri Yanıbaşımızdaki Tarih İ̧̧in Bir Kılavuz, İstanbul: Tarih Vakfi Yurt Yayınları.

Demirseren Çöl, Şölen (1998). Kentlerimizde Kimlik Sorunu ve Günümüz Kentlerinin Kimlik Derecesini Ölçmek İçin Bir Yöntem Denemesi, Yayınlanmamı̧̧ Doktora tezi, İstanbul: Mimar Sinan Üniversitesi.

Dereli, Turgut (2008). Bizim Yaşadiğımız Muğla, İzmir: A kare Matbaacılık. Eroğlu, Zekai (2011). Muğla Taribi, Muğla: Muğla Belediyesi Kültür Yayınları.

Ekinci, Oktay (1985). Yaşayan Muğla, İstanbul: Bilimsel Eserler Kolektif Şirketi.

Ergenç, Özer (1984). "Osmanlı Şehrindeki Mahallenin İşlev ve Nitelikleri Üzerine”, The Journal Of Ottoman Studies, IV, s. 69-78.

Ergin, Nilüfer (2001). “Ortak Yaşam Alanı Olarak Heykel”, 21. Yüzyıl Karşısında Kent ve İnsan, (Haz. F. Gümüşoğlu), İstanbul: Bağlam Yayınları.

Evliya Celebi Seyahatnamesi (2011). (Haz. Dağlı, Yücel, Seyit Ali Kahraman ve Robert Dankoff), Cilt 9, İstanbul: Yap1 Kredi Yayınları.

Faroqhi, Suraiya (2006). Osmanl Şehirleri ve Kırsal Hayatı, (Çev. Emine Sonnur Özcan) Ankara: Doğubat1.

Işık, Hasan (2008). "İlköğretimde Tarih Konularının Yerel Tarih İle İlişkilendirilmesinin Öğrenci Başarısına Etkisi”, Uluslararası Sosyal Araștırmalar Dergisi, Volume 1/4, s. 290-310.

İlyasoğlu, Aynur (2001). Yerel Tarihçilik, Kent, Sivil Girişim, İstanbul: Tarih Vakfi Yurt Yayınları.

Kuban, Doğan (1968). "Anadolu Türk Şehri Tarihi Gelişmesi, Sosyal ve Fiziki Özellikleri Üzerinde Bazı Gelişmeler”, Vakıflar Dergisi, Sayı VII, s. 53-73.

Lefebvre, Henri (2010). Gündelik Hayatın Eleştirisi 2, (Çev. Işı Ergüden), İstanbul: Sel Yayıncilı.

Oktay, Derya (2001). "Kentsel Tasarımın Kuramsal Çerçevesine Güncel Bir Bakış: Kentlerimiz, Yaşam Kalitesi ve Sürdürülebilirlik”, Mimarlık, Sayı 302, s. 45-49. 
Ortaylı, İlber (2009). Osmanlı Toplumunda Aile, İstanbul: Timaş Yayınları.

Osmay Sevin (2006). "1950-1987 Döneminde Muğla Kenti”, Tarih İ̧̧inde Muğla (Der. İlhan Tekeli) Muğla: Muğla Belediyesi Yayınları, 2. Baskı, s. 188-239.

Önal, Mehmet Naci (2007). "Sözlü Kültür, Folklor ve Sözlü Tarih”, Yerel Tarih Yöntem ve Deneyimler II. Sözlü Tarih Atölyesi, Muğla: Muğla Belediyesi Kültür Yayınları, s. 24-38.

Öz, Mehmet (2005). "Osmanlı Klasik Döneminde Anadolu Kentleri", Türkiye Araștırmaları Literatür Dergisi. C. 3, Sayı 6, s. 57-88.

Öztürk, Serdar (2013). "Türkiye'de Sinema Mekânlarını Sözlü Tarih Üzerinden Anlamak", Milli Folklor, 98, s. 19-31.

Peçevi İbrahim Efendi (1981). Peçevi Taribi. C. 2, (Haz. Bekir Sıtkı Baykal), Ankara: Kültür Bakanlığı Yayınları.

Solak, Sevcan Güleç (2017). "Mekân-Kimlik Etkileşimi: Kavramsal ve Kuramsal Bir Bakış”, Manas Sosyal Araștırmalar Dergisi, C. 6, Sayı 1, s. 13-37.

Şahin, Erman (2004). Muğla Yazıları, Muğla: Muğla Üniversitesi Basımevi.

Talen, Emily ve Yusuf Şahin (2002). "Topluluk Duygusu ve Mahalle Biçimi: Yeni Kentçi Sosyal Öğretinin Bir Değerlendirmesi”, Mülkiye. C. XXVI, Say1 233, s. 143-173.

Tekeli, İlhan (2006). “1923-1950 Döneminde Muğla'da Olan Gelişmeler”, Tarib İ̧̧inde Muğla, (Der. İlhan Tekeli), Muğla: Muğla Belediyesi Yayınları, (2. Bask1), s. 114-187.

Thompson, Paul (1999). Geçmişin Sesi Sözlü Tarib, (Çev. Şehnaz Layıkel), İstanbul: Tarih Vakfi Yurt Yayınları.

Tosh, John (2011). Taribin Peşinde Modern Tarib Çalışmasında Hedefler, Yöntemler Ve Yeni Doğrultular, (Çev. Özden Arıkan), İstanbul: Tarih Vakfı Yurt Yayınları.

Tuncel, Harun (2009). "Geleneksel Ticaret Mekânı Olarak Türkiye'de Haftalık Pazarlar", e- journal of Nerw World Sciences Academy, Volume 4, Number 2, s. 35-52.

Türköz, Ünal (2018). "Muğla’da Kaybolan Bir Meslek: Nalbantlık”, Menteşe Kültür-Sanat-Tarih, Y11 4, say1 8, s. 90-91. 
Uzunçarş1l1, İsmail Hakkı (1929). Anadolu Kitabeleri II. Kitap Afyonkarahisar, Sandikl, Bolvadin, Çay, İsaklı, Manisa, Birgi, Muğla, Milas, Peçin, Denizli, Isparta, Atabey ve Eğridir, İstanbul.

Yaşar, Ahmet (2005). "Osmanlı Şehir Mekânları: Kahvehane Literatürü”, TALID Dergisi, C. 3, S. 6, s. 237-256.

\section{Kaynak Kişiler}

K1: Bahattin Topbaş. (2018) Muğla/Menteşe, 64, Emekli.

K2: Hamdi Yumuk. (2018) Muğla/Menteşe, 83, Emekli şoför.

K3: Şerif Şalk. (2018) Muğla/Menteşe, 70, Türk Hava Kurumu Başkanı.

K4: İbrahim Ergin. (2018) Muğla/Menteşe, 81, Yazar-şair.

K5: Sadettin Özbek. (2018) Muğla/Menteşe, 64, Muğla Sanat Severler Derneği Başkanı.

K6: Şener Öner. (2018) Muğla/Menteşe, 77, Emekli.

K7: Hamdi Dural. (2018) Muğla/Menteşe, 78, Çiftçi.

K8: Fatma Sarı. (2018) Muğla/Çomakdağ, 49, Esnaf.

K9: Mehmet Demirtaş. (2018) Muğla/Menteşe, 78, Emekli.

K10: Erol Kutlay. (2018) Muğla/Menteşe, 77, Sinema Sahibi.

K11: Zeliha Korkmaz. (2018) Muğla/Menteşe, 95, Emekli Öğretmen. 